\title{
PENGARUH PENGETAHUAN DAN KESADARAN WAJIB PAJAK TERHADAP KEPATUHAN WAJIB PAJAK DALAM MEMBAYAR PAJAK BUMI DAN BANGUNAN (PBB)
}

\author{
Siti Salmah ${ }^{1)}$ \\ Sekolah Tinggi Ilmu Ekonomi-LPI Makasar \\ salmah.sharon@gmail.com
}

\begin{abstract}
This research is intended to determine the effect of knowledge and awareness of taxpayers on taxpayer compliance in paying Land and Building Tax (PBB) in Manggala Sub-district, Makassar City. The sample in this research is the existing taxpayer District Manggala Kota Makassar as many as 100 respondents. The techniquesampling in this research is using simple random sampling. The type of data used in this study is quantitative data in the form of scores or scores on answers given by respondents to the questions that exist in the questionnaire. Sources of data used are primary data and secondary data. Primary data obtained from direct observation, interview, questionnaire and observation while secondary data obtained by researcher in the form of data report of result of tax payment from research object. Methods of data analysis using data quality test, classical assumption test, multiple regression analysis and hypothesis test. Based on the results of research that has been done can be concluded that there is a significant positive influence between taxpayer knowledge and taxpayer awareness of taxpayer compliance in paying taxes of the earth and buildings.
\end{abstract}

Keywords:Knowledge, Taxpayer Awareness, Taxpayer Compliance

\begin{abstract}
Abstrak
Penelitian ini bertujuan untuk mengetahui pengaruh pengetahuan dan kesadaran wajib pajak terhadap kepatuhan wajib pajak dalam membayar Pajak Bumi dan Bangunan (PBB) di Kecamatan Manggala Kota Makassar. Sampel dalam penelitian ini wajib pajak yang ada Kecamatan Manggala Kota Makassar sebanyak 100 responden. Teknik pengumpulan sampel yang digunakan dalam penelitian ini adalah menggunakan simple random sampling. Adapun jenis data yang digunakan dalam penelitian ini adalah data kuantitatif yang berupa nilai atau skor atas jawaban yang diberikan oleh responden terhadap pertanyaan-pertanyaan yang ada dalam kuesioner. Sumber data yang digunakan yaitu data primer dan data sekunder. Data primer diperoleh dari pengamatan langsung, wawancara, kuisioner dan observasi sedangkan data sekunder diperoleh peneliti berupa data laporan hasil setoran pajak dari obyek penelitian. Metode analisis data menggunakan uji kualitas data, uji asumsi klasik, analisis regresi berganda dan uji hipotesis. Berdasarkan hasil penelitian yang telah dilakukan dapat diambil kesimpulan bahwa terdapat pengaruh positif yang signifikan antara pengetahuan wajib pajak dan kesadaran wajib pajak terhadap kepatuhan wajib pajak dalam membayar pajak bumi dan bangunan.
\end{abstract}

Kata Kunci : Pengetahuan, Kesadaran Wajib Pajak, Kepatuhan Wajib Pajak 


\section{LATAR BELAKANG}

Pajak merupakan salah satu sumber pembiayaan pembangunan nasional dalam rangka peningkatan masyarakat. Pajak memiliki peran yang sangat penting terhadap pendapatan negara pada masa sekarang. Ini terjadi karena pajak adalah sumber yang pasti dalam memberikan kontribusi kepada negara. Berkaitan dengan hal tersebut pentingnya pengelolaan pajak tersebut menjadi prioritas bagi pemerintah. Ada berbagai jenis pajak yang dikenakan kepada masyarakat, salah satunya yaitu Pajak Bumi dan Bangunan.

Pajak Bumi dan Bangunan merupakan salah satu faktor pemasukan bagi negara yang cukup potensial terhadap pendapatan negara. Strategisnya Pajak Bumi dan Bangunan tidak lain karena objek pajak meliputi seluruh bumi dan bangunan yang berada dalam wilayah Negara Kesatuan Republik Indonesia. Meskipun Pajak Bumi dan Bangunan dianggap sebagai sumber dana yang potensial bagi pembiayaan negara, namun dalam realisasinya pemungutan pajak masih sulit dilakukan oleh negara. Hal ini disebabkan masih rendahnya tingkat kepatuhan wajib pajak dan kepercayaan mastyarakat kepada administrasi pengelolaan pajak.

Kepatuhan yang tinggi dari wajib pajak PBB dibutuhkan untuk kelancaran penarikan pajak. Kepatuhan wajib pajak adalah salah satu keadaan dimana wajib pajak memenuhi semua kewajiban perpajakan dan melaksanakan hak perpajakannya. Namun dalam kenyataanya negara sering kesulitan memungut pajak, termasuk Pajak Bumi dan Bangunan. Masalah kepatuhan wajib pajak adalah masalah penting, baik bagi negara maju maupun negara berkembang (Kurnia, 2010). Karena jika wajib pajak tidak patuh maka akan menimbulkan keinginan untuk melakukan tindakan penghindaraan, pengelakan, penyelundupan dan pelalaian pajak yang pada akhirnya tindakan tersebut akan menyebabkan penerimaan pajak negara akan berkurang (Kurnia, 2010). Administrasi perpajakan di Indonesia 
masih perlu diperbaiki, dengan Makassar, realisasi penerimaan pajak perbaikan diharapkan wajib pajak dari tahun 2012 sampai 2016 lebih termotivasi dalam memenuhi mengalami kenaikan dan penurunan kewajiban perpajakannya. Wajib dari potensi penerimaan pajak. Pada pajak akan patuh karena mereka tabel 1 dibawah ini dapat dilihat berfikir adanya sanksi berat akibat tingkat pencapaian penerimaan Pajak tindakan ilegal dalam usahanya untuk Bumi dan Bangunan di Kecamatan menyulundupkan pajak. Manggala Kota Makassar tahun 2012-

Fenomena empiris kepatuhan 2016.

wajjib pajak Di Kecamatan Manggala Kota Makassar, berdasarkan data dari Dinas Pendapatan Daerah Kota

Tabel 1. Tingkat Penerimaan Pajak Bumi dan Bangunan Di Kecamatan Manggala Kota Makassar Tahun 2012 - 2016

\begin{tabular}{cccc}
\hline Tahun & $\begin{array}{c}\text { Potensi Penerimaan } \\
\text { Pajak }\end{array}$ & Realisasi PBB & $\begin{array}{c}\text { Persentase } \\
\text { Pencapaian (\%) }\end{array}$ \\
\hline 2012 & Rp. 4.087 .317 .384 & Rp. 2.791.488.168 & 68,30 \\
2013 & Rp. 5.356.734.725 & Rp. 3.146.035.521 & 58,73 \\
2014 & Rp. 5.359 .143 .498 & Rp. 3.363.635.638 & 62,76 \\
2015 & Rp. 7.406.459.674 & Rp. 4.190.783.822 & 56,58 \\
2016 & Rp. 7.668.087.235 & Rp. 4.747.777.863 & 61,92 \\
\hline \multicolumn{2}{l}{ Sumber: DISPENDA Kota Makassar, 2017 } & &
\end{tabular}

Tabel 2. Tingkat Kepatuhan Wajib Pajak PBB Di Kecamatan Manggala Kota Makassar Tahun 2012 - 2016

\begin{tabular}{cccc}
\hline Tahun & $\begin{array}{c}\text { WP } \\
\text { (SPPT) }\end{array}$ & $\begin{array}{c}\text { Realisasi } \\
\text { (SPPT) }\end{array}$ & $\begin{array}{c}\text { Persentase } \\
\text { Pencapaian }(\%)\end{array}$ \\
\hline 2012 & 37.995 & 12.046 & 31,71 \\
2013 & 41.277 & 18.776 & 45,48 \\
2014 & 41.846 & 19.957 & 47,69 \\
2015 & 41.899 & 29.430 & 70,24 \\
2016 & 43.372 & 31.740 & 73,18 \\
\hline
\end{tabular}

Sumber: DISPENDA Kota Makassar, 2017 
Kecamatan Manggala

merupakan kecamatan yang pontensial dalam penerimaan PBB. Wajib pajak yang terdaftar di Kecamatan Manggala pada tahun 2016 yaitu sebanyak 43.372 orang. Dilihat dari realisasi $\mathrm{PBB}$ tahun anggaran 2016 menunjukkan bahwa jumlah realisasi PBB sebesar Rp. 4.747.777.863 dari jumlah wajib pajak 43.372 orang. Sementara ketetapan PBB tahun anggaran 2016 sebesar Rp. 7.668.087.235. Jadi dapat dilihat realisasi PBB hanya $61,92 \%$, dan terdapat 11.632 wajib pajak PBB non efektif. Dikatakan non efektif karena tidak melakukan pemenuhan kewajiban perpajakannya.

Hasil penelitian terdahulu seperti yang dilakukan oleh Mustofa (2011) melakukan penelitian mengenai pengaruh penghasilan dan kesadaran wajib pajak terhadap kepatuhan wajib pajak dalam membayar pajak bumi dan bangunan (PBB) di kelurahan tembalang semarang tahun 2009. Hasil penelitian menunjukkan bahwa ada pengaruh yang signifikan antara penghasilan dan kesadaran wajib pajak secara simultan terhadap kepatuhan wajib pajak dalam membayar pajak bumi dan bangunan.

Utomo (2011) melakukan penelitian mengenai pengaruh sikap, kesadaran wajib pajak, dan pengetahuan perpajakan terhadap kepatuhan wajib pajak dalam membayar pajak bumi dan bangunan di kecamatan pamulang kota tangerang selatan. Hasilnya menujukkan bahwa secara parsial sikap wajib pajak tidak berpengaruh secara signifikan terhadap kepatuhan wajib pajak, pengetahuan perpajakan berpengaruh secara signifikan terhadap kepatuhan wajib pajak, dan secara simultan sikap wajib pajak, kesadaran wajib pajak, dan pengetahuan perpajakan berpengaruh secara signifikan terhadap kepatuhan wajib pajak. 


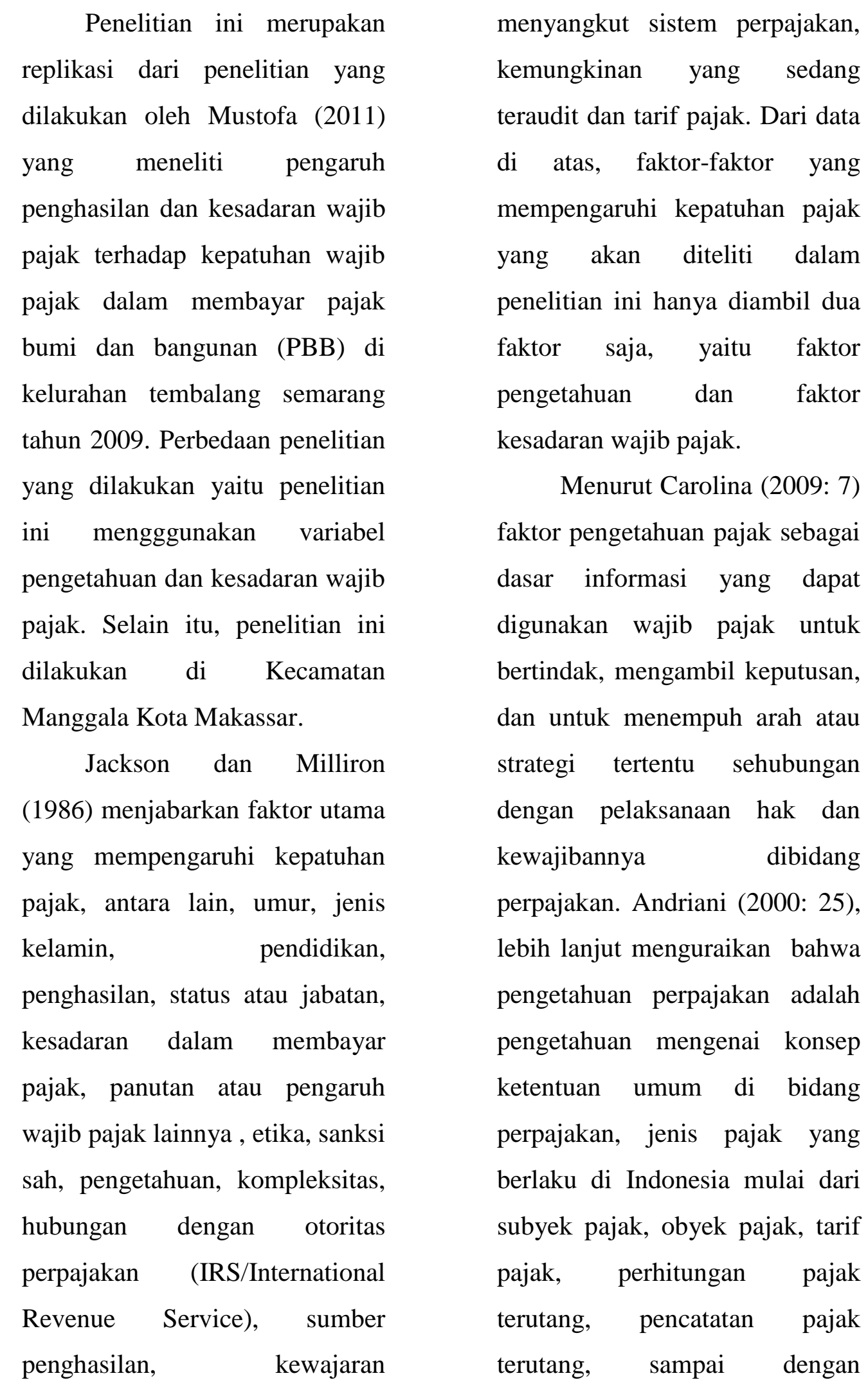


bagaimana pengisian pelaporan pajak.

Selain faktor pengetahuan, faktor kesadaran dalam membayar pajak juga dianggap sebagai hal yang penting dalam kaitan dengan kepatuhan membayar pajak. Seperti yang diungkapkan Suhardito \& Sudibyo (1999) kesadaran wajib pajak merupakan konstelasi komponen kognitif, afektif, kognitif, yang berinteraksi dalam memahami, merasakan, dan berperilaku terhadap makna dan fungsi pajak. Kesadaran perpajakan berkonsekuensi logis untuk para wajib pajak agar mereka rela memberikan kotribusi dana untuk pelaksanaan fungsi perpajakan, dengan cara membayar kewajiban pajaknya secara tepat waktu dan tepat jumlah.

Berdasarkan uraian yang telah dikemukakan di atas maka peneliti akan melakukan penelitian berkaitan dengan pengaruh pengetahuan dan kesadaran wajib pajak terhadap kepatuhan wajib pajak dalam membayar pajak bumi dan bangunan (PBB) di Kecamatan Manggala Kota Makassar.

\section{TINJAUAN PUSTAKA}

\section{Theoryof Planned Behavior}

Ajzenmengembangkantheoryofpl annedbehavior(TPB)inipadatahu $\mathrm{n}$ 1988.Ajzen(1988)menambahkans ebuah konstrukyangbelumada di TRA. Konstruk ini disebut dengan control perilaku persepsian. Berdasarkan teori ini, prilaku individu untuk tidak atau patuh terhadap ketentuan perpajakan dipengaruhi oleh niat untuk berprilaku.Jogiyanto (2007:61)menjelaskan teori perilaku rencanamerupakan pengembanganlebih lanjutdaritheoryof reasonedaction(TRA).Sedangkan munculnyaniatuntuk berperilakuditentukanoleh tigafaktor,yaitu:
a) Behavioral beliefs
Behavioralbeliefs merupakan keyakinan 
individuakanhasildarisuatu

perilakudan evaluasi

atashasil tersebut.

b) Normative beliefs

Normativebeliefsmerupakan

keyakinantentangharapannor

matiforang lain dan motivasi

untukmemenuhiharapanterse

but.

c) Control beliefs

Controlbeliefsmerupakan

keyakinan tentang

keberadaanhal-halyang

mendukungatau

menghambatperilakuyangaka

nditampilkan dan

persepsinya tentang

seberapa kuat hal-hal yang

mendukung dan

menghambatperilakunya

tersebut (perceivedpower).

\section{TeoriAtribusi}

Teoriatribusipertama

kaliditemukanolehHeiderpadat ahun1958dan

kemudiandikembangkanoleh

Weinerpadatahun1974.Teoriat

ribusi mengasumsikan

bahwaorangmencobauntukme

nentukan mengapaorang melakukanapayangmereka

lakukan,yaitu atribut

menyebabkan perilaku.

Seseorangberusahauntukmem

ahamimengapa

oranglainmelakukansesuatu

yangmungkinsatuataulebihatri

butmenyebabkanperilakuitu.

Weiner(1974:27-42)

menjelaskansebuahproses

tigatahapmendasari suatu

atribusi, yaitu:

a) Orangharusmelihatataume ngamatiperilaku

b) Maka orangharuspercaya bahwa perilaku itusngaja dilakukan, dan

c) Maka orangharus menentukanapakahmerek

a percaya yangoranglain dipaksauntuk melakukan perilakuatautidak.

\section{TeoriPembelajaran Sosial}

Teoribelajarsosialdikenal kanolehBandurapadatahun198

6.Konsep

dariteoriinimenekankanpada

komponen

kognitifdaripikiran,pemahama

ndan 
evaluasi.Faktorsosialdankogni

tif serta faktor

pelakumemainkan peran

penting dalam pembelajaran.

Faktor

kognitif

berupaekspektasi/penerimaanu

ntukmeraihkeberhasilan,sedan

gkan faktor sosial mencakup

pengamatan. Teori ini

merupakan perluasan teori

pengkondisianperandariSkinn

eryaituteori

yangmengandaikan perilaku

sebagaisuatu fungsidari

konsekuensi-

konsekuensinya.Bandura(1986

) mengatakanbahwa proses

dalampembelajaransosial

meliputi:

a) Proses

Perhatian(attentional)

Prosesperhatian yaitu

oranghanyaakanbelajardar

iseseorangatau model,jika

mereka

telahmengenaldanmenaru

hperhatianpadaorang

ataumodel tersebut.

b) ProsesPenyimpanan(reten

tion)
Prosespenyimpananadalah

prosesmengingattindakans

uatu model

setelahmodeltidaklagimud ahtersedia.

c) ProsesReproduksiMotorik

Prosesreproduksimotorika

dalahprosesmengubahpen

gamatanmenjadi

perbuatan.

d) ProsesPenguatan(reinforc

ement)

Prosespenguatan adalah proses yangmana

individu-individu

disediakan

rangsanganpositifatau

penghargaansupayaberper

ilaku sesuaidengan model.

\section{RUMUSAN MASALAH}

Berdasarkan latar belakang penelitian yang telah diuraikan di atas, maka dirumuskan masalah sebagai berikut:

1. Apakah pengetahuan berpengaruh terhadap kepatuhan wajib pajak dalam membayar pajak bumi dan bangunan (PBB) 
di Kecamatan Manggala Kota Makassar?

2. Apakah kesadaran wajib pajak berpengaruh terhadap kepatuhan wajib pajak dalam membayar pajak bumi dan bangunan (PBB) di Kecamatan Manggala Kota Makassar?

3. Apakah pengetahuan dan kesadaran wajib pajak berpengaruh secara simultan terhadap kepatuhan wajib pajak dalam membayar Pajak Bumi dan Bangunan (PBB) di Kecamatan Manggala Kota Makassar?

\section{HIPOTESIS PENELITIAN}

Hipotesis penelitian merupakan jawaban sementara dari permasalahan penelitian yang biasa dirumuskan dalam bentuk yang dapat diuji secara empirik (Hasan, 2002:50). Hipotesis yang diajukan dalam penelitian ini adalah:

$$
\begin{aligned}
\mathrm{H}_{1}= & \text { Ada pengaruh positif yang } \\
& \text { signifikan antara pengetahuan } \\
& \text { Wajib Pajak terhadap } \\
& \text { kepatuhan Wajib Pajak dalam }
\end{aligned}
$$

membayar Pajak Bumi dan Bangunan.

$\mathrm{H}_{2}=$ Ada pengaruh positif yang signifikan antara kesadaran Wajib Pajak terhadap kepatuhan Wajib Pajak dalam membayar Pajak Bumi dan Bangunan.

$\mathrm{H}_{3}=$ Ada pengaruh positif yang signifikan antara pengetahuan dan kesadaran Wajib Pajak terhadap kepatuhan Wajib Pajak dalam membayar Pajak Bumi dan Bangunan.

\section{POPULASI DAN SAMPEL}

\section{Populasi}

Populasi

dalampenelitianiniadalahselur uhWajib Pajak PBBdi Kecamatan Manggala yang terdaftar di DISPENDA Kota Makassar.

Jumlahpopulasidalam penelitian iniyaitu 43.372Wajib Pajak PBB.

2. Sampel

\begin{tabular}{lr}
\multicolumn{1}{c}{ Perhitungan } & sampel \\
dilakukan & dengan \\
menggunakan rumus & Slovin
\end{tabular}


dengan asumsi bahwa bahwa populasi tersebut berdistribusi normal.Penentuan sampel ditentukan dengan menggunakan rumus berikut (Muliari dan Setiawan,2010):

$$
n=\frac{N}{1+N(e)^{2}}
$$

Dimana :

$$
n=\text { JumlahSampel }
$$$$
N=\text { Populasi }
$$

$e=$ Batas kesalahan maksimal yang ditolerir dalam sampel (10\%)

$$
\begin{gathered}
n=\frac{N}{1+N(e)^{2}} \\
n=\frac{43.372}{1+43.372(0,1)^{2}} \\
n=\frac{43.372}{1+433,72}
\end{gathered}
$$

$n=99,76$ (Dibulatkan 100)

\begin{tabular}{lrr} 
Berdasarkan & \multicolumn{2}{r}{ perhitungan } \\
diatas, maka & sampel & dalam \\
penelitian ini & adalah & 99,76 \\
dibulatkan menjadi & 100 \\
responden. & Teknik \\
pengumpulan sampel yang & san \\
digunakan dalam penelitian ini \\
adalah menggunakan simple
\end{tabular} random sampling. Simple random sampling yaitu cara pengambilan sampel dari semua anggota populasi yang dilakukan secara acak tanpa memerhatikan strata yang ada dalam anggota populasi.

\section{JENIS DAN SUMBER DATA}

Adapun jenis data yang digunakan dalam penelitian ini adalah data kuantitatif yang berupa nilai atau skor atas jawaban yang diberikan oleh responden terhadap pertanyaanpertanyaan yang ada dalam kuesioner. Sumber data yang digunakan yaitu data primer dan data sekunder. Data primer diperoleh dari pengamatan langsung, wawancara, kuisioner dan observasi sedangkan data sekunder diperoleh peneliti berupa data laporan hasil setoran pajak dari obyek penelitian.

\section{TEKNIK ANALISIS DATA}

Metode analisis data menggunakan uji kualitas data, uji asumsi klasik, analisis regresi berganda dan uji hipotesis. 
HASIL DAN PEMBAHASAN

\section{A. Hasil Penelitian}

\section{Gambaran Umum Responden}

Penelitian ini

menggunakan data kuantitatif yang diperoleh dari penyebaran kuesioner kepada wajib pajak PBB yang bertempat tinggal di Kecamatan Manggala Kota Makassar. Kuesioner disebarkan kepada 100 responden.

\section{Karakteristik Responden}

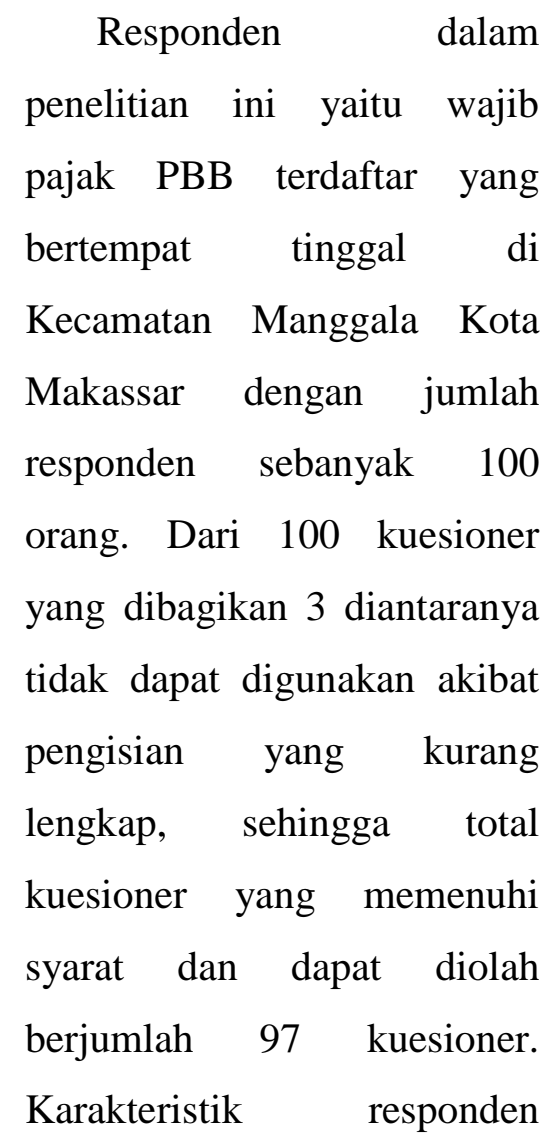

dikelompokkan menurut jenis kelamin, pendidikan terakhir dan status. Berdasarkan tabel 5 dibawah dapat dilihat responden yang berjenis kelamin laki-laki berjumlah 47 orang, kemudian diikuti responden yang berjenis kelamin perempuan berjumlah 50 orang. Selanjutnya dapat dilihat responden rata-rata berpendidikan tingkat akhir, tingkat pendidikan responden yang berpendidikan tingkat akhir perguruan tinggi yang meliputi D3, S1, S2 lebih banyak yaitu berjumlah 69 orang, kemudian diikuti responden yang berpendidikan tingkat SMP, SMA/Sederajat yang berjumlah 28 orang. Responden. Kemudian diikuti oleh status responden, dimana jumlah responden yang menikah sebanyak 81 orang dan yang belum menikah sebanyak 16 orang.

Pada tabel 5 dibawah ini dijelaskan karakteristik responden sebagai berikut. 
Tabel 5. Karakteristik Responden

\begin{tabular}{clcc}
\hline Jenis Kategori & \multicolumn{1}{c}{ Keterangan } & Jumlah & Persentase \\
\hline \multirow{2}{*}{ Jenis Kelamin } & a. Laki-Laki & 47 & $48,45 \%$ \\
& b. Perempuan & 50 & $51,55 \%$ \\
& a. SD & 0 & \\
& b. SMP & 1 & $1,03 \%$ \\
Pendidikan & c. SMA/Sederajat & 27 & $27,84 \%$ \\
Terakhir & d. D3 & 10 & $10,31 \%$ \\
& e. S1 & 41 & $42,27 \%$ \\
& f. S2 & 18 & $18,56 \%$ \\
Status & a. Menikah & 81 orang & $83,51 \%$ \\
& b. Belum Menikah & 16 orang & $16,49 \%$ \\
\hline
\end{tabular}

Sumber : Data Primer Diolah, 2017

3. Deskriptif Variabel

Data Deskriptif

menampilkan gambaran

umum mengenai jawaban

responden atas pernyataan

yang terdapat dalam

kuesioner.berdasarkan

kuesioner yang telah

dibagikan, maka peneliti akan

menguraikan secara rinci

jawaban responden yang

dikelompokkan dalam deskriptif statistik. Variabelvariabel dalam penelitian ini diukur dengan menggunakan skala likert lima point dari Sangat Setuju/Sangat Tahu (5), Setuju/Tahu (4), Kurang Setuju/Cukup Tahu (3), Tidak Setuju/Kurang Tahu (2), Sangat Tidak Setuju/Tidak Tahu (1). 


\section{Tabel 6 . Frekuensi Tanggapan Responden}

a) Pengetahuan WP $\left(\mathbf{X}_{1}\right)$

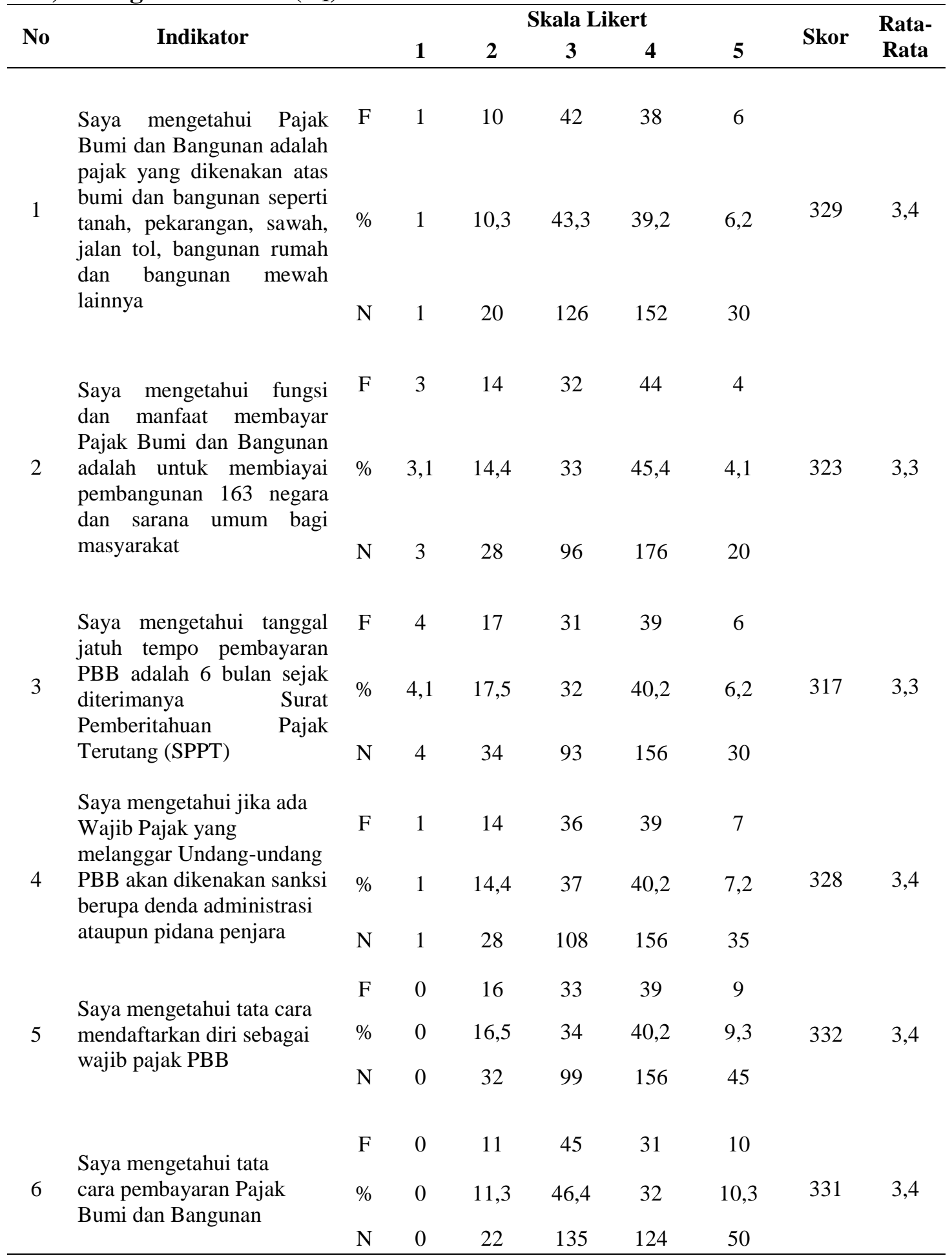

Sumber : Data Primer Diolah, 2017 


\section{b) Kesadaran WP $\left(\mathbf{X}_{2}\right)$}

\begin{tabular}{|c|c|c|c|c|c|c|c|c|c|}
\hline \multirow{2}{*}{ No } & \multirow{2}{*}{ Indikator } & & \multicolumn{5}{|c|}{ Skala Likert } & \multirow{2}{*}{ Skor } & \multirow{2}{*}{$\begin{array}{l}\text { Rata- } \\
\text { Rata }\end{array}$} \\
\hline & & & 1 & 2 & 3 & 4 & 5 & & \\
\hline \multirow{3}{*}{1} & Saya setuju bahwa membayar & $\mathrm{F}$ & 0 & 12 & 36 & 46 & 3 & \multirow{3}{*}{331} & \multirow{3}{*}{3,4} \\
\hline & $\begin{array}{l}\text { pajak merupakan suatu } \\
\text { kewajiban yang harus ditaati }\end{array}$ & $\%$ & 0 & 12,3 & 40,2 & 47,4 & 3,1 & & \\
\hline & Oirn setrap warga ive gara & $\mathrm{N}$ & 0 & 24 & 108 & 184 & 15 & & \\
\hline \multirow{3}{*}{2} & Saya setuju bahwa & $\mathrm{F}$ & 0 & 14 & 38 & 34 & 11 & \multirow{3}{*}{333} & \multirow{3}{*}{3,4} \\
\hline & $\begin{array}{l}\text { pemungutan Pajak Bumi dan } \\
\text { Bangunan hasilnya akan }\end{array}$ & $\%$ & 0 & 14,4 & 39,2 & 35,1 & 11,3 & & \\
\hline & kembali ke masyarakat & $\mathrm{N}$ & 0 & 28 & 114 & 136 & 55 & & \\
\hline \multirow{3}{*}{3} & $\begin{array}{l}\text { Dengan membayar Pajak Bumi } \\
\text { dan Bangunan, maka akan }\end{array}$ & $\mathrm{F}$ & 1 & 15 & 40 & 33 & 8 & \multirow{3}{*}{323} & \multirow{3}{*}{3,3} \\
\hline & $\begin{array}{lr}\text { meningkatkan } & \text { sumber } \\
\text { pembiayaan } & \text { pembangunan }\end{array}$ & $\%$ & 1 & 15,5 & 41,2 & 34 & 8,2 & & \\
\hline & nasional & $\mathrm{N}$ & 1 & 30 & 120 & 132 & 40 & & \\
\hline \multirow{3}{*}{4} & $\begin{array}{l}\text { Pajak Bumi dan Bangunan } \\
\text { merupakan salah satu faktor }\end{array}$ & $\mathrm{F}$ & 4 & 18 & 40 & 22 & 13 & \multirow{3}{*}{313} & \multirow{3}{*}{3,2} \\
\hline & $\begin{array}{l}\text { pemasukan bagi negara yang } \\
\text { cukup potensial terhadap }\end{array}$ & $\%$ & 4,1 & 18,6 & 41,2 & 22,7 & 13,4 & & \\
\hline & pendapatan negara & $\mathrm{N}$ & 4 & 36 & 120 & 88 & 65 & & \\
\hline \multirow{3}{*}{5} & Dengan adanya tingkat & $\mathrm{F}$ & 5 & 19 & 39 & 27 & 7 & \multirow{3}{*}{303} & \multirow{3}{*}{3} \\
\hline & $\begin{array}{l}\text { tinggi terhadap kinerja aparat } \\
\text { pajak dapat meningkatkan } \\
\text { kesadaaran masyarakat akan }\end{array}$ & $\%$ & 5,15 & 19,6 & 40,2 & 27,8 & 7,2 & & \\
\hline & pentingnya pajak & $\mathrm{N}$ & 5 & 38 & 117 & 108 & 35 & & \\
\hline \multirow{3}{*}{6} & $\begin{array}{l}\text { Dengan adanya pemahaman } \\
\text { yang disosialisasikan kepada } \\
\text { masyarakat melalui kampanye }\end{array}$ & $\mathrm{F}$ & 3 & 19 & 40 & 30 & 5 & \multirow{3}{*}{306} & \multirow{3}{*}{3,2} \\
\hline & $\begin{array}{l}\text { sadar akan pajak seperti } \\
\text { seminar dapat meningkatkan }\end{array}$ & $\%$ & 3,1 & 19,6 & 41,2 & 31 & 5,2 & & \\
\hline & $\begin{array}{l}\text { kesadaran dalam membayar } \\
\text { pajak }\end{array}$ & $\mathrm{N}$ & 3 & 38 & 120 & 120 & 25 & & \\
\hline
\end{tabular}

Sumber : Data Primer Diolah, 2017 
c) Kepatuhan WP (Y)

\begin{tabular}{|c|c|c|c|c|c|c|c|c|c|}
\hline \multirow{2}{*}{ No } & \multirow{2}{*}{ Indikator } & & \multicolumn{5}{|c|}{ Skala Likert } & \multirow{2}{*}{ Skor } & \multirow{2}{*}{$\begin{array}{l}\text { Rata- } \\
\text { Rata }\end{array}$} \\
\hline & & & $\mathbf{1}$ & 2 & 3 & 4 & 5 & & \\
\hline \multirow{3}{*}{1} & Membayar pajak bumi dan & $\mathrm{F}$ & 0 & 11 & 38 & 39 & 9 & \multirow{3}{*}{337} & \multirow{3}{*}{3,5} \\
\hline & $\begin{array}{ll}\text { waktu } & \text { merupakan } \\
\text { kewajiban } & \text { saya sebagai }\end{array}$ & $\%$ & 0 & 11,3 & 39,2 & 40,2 & 9,3 & & \\
\hline & $\begin{array}{lr}\text { warga Negara yang patuh } \\
\text { terhadap } & \text { peraturan } \\
\text { perpajakan } & \end{array}$ & $\mathrm{N}$ & 0 & 22 & 114 & 156 & 45 & & \\
\hline \multirow{3}{*}{2} & $\begin{array}{l}\text { Saya mendaftarkan diri } \\
\text { sebagai wajib pajak untuk }\end{array}$ & $\mathrm{F}$ & 0 & 17 & 40 & 34 & 6 & \multirow{3}{*}{320} & \multirow{3}{*}{3,3} \\
\hline & $\begin{array}{l}\text { memenuhi kewajiban saya } \\
\text { sebagai warga negara yang }\end{array}$ & $\%$ & 0 & 17,5 & 41,2 & 35 & 6,2 & & \\
\hline & baik & $\mathrm{N}$ & 0 & 34 & 120 & 136 & 30 & & \\
\hline \multirow{3}{*}{3} & Setelah menerima SPPT & $\mathrm{F}$ & 0 & 14 & 44 & 30 & 9 & \multirow{3}{*}{325} & \multirow{3}{*}{3,4} \\
\hline & $\begin{array}{l}\text { Pajak Bumi dan Bangunan, } \\
\text { harus segera dibayar }\end{array}$ & $\%$ & 0 & 14,4 & 45,4 & 31 & 9,3 & & \\
\hline & pembayaran & $\mathrm{N}$ & 0 & 28 & 132 & 120 & 45 & & \\
\hline \multirow{3}{*}{4} & Saya setuju dan bersedia & $\mathrm{F}$ & 0 & 10 & 37 & 42 & 8 & \multirow{3}{*}{339} & \multirow{3}{*}{3,5} \\
\hline & $\begin{array}{l}\text { informasi kepada pihak } \\
\text { fiskus mengenai harta }\end{array}$ & $\%$ & 0 & 10,3 & 38 & 43,3 & 8,2 & & \\
\hline & $\begin{array}{l}\text { kekayaan yang saya miliki } \\
\text { (tanah dan bangunan) }\end{array}$ & $\mathrm{N}$ & 0 & 20 & 111 & 168 & 40 & & \\
\hline
\end{tabular}

Sumber : Data Primer Diolah, 2017 
Berdasarkan tabel 6 diatas, untuk variabel Pengetahuan $\left(\mathrm{X}_{1}\right)$ dapat disimpulkan bahwa pengetahuan perpajakan wajib pajak PBB di Kecamatan Manggala masih cukup rendah. Hal ini dapat dibuktikan dengan nilai skor rata-rata setiap pernyataan berkisar antara 3,3 - 3,4. Untuk variabel Kesadaran $\left(\mathrm{X}_{2}\right)$ memiliki nilai skor rata-rata berkisar antara $3-3,4$ yang berarti bahwa tingkat kesadaran wajib pajak PBB di Kecamatan manggala juga cukup rendah. Selanjutnya untuk variabel Kepatuhan (Y), memiliki nilai skor rata-rata berkisar antara $3,3-3,5$ yang berarti wajib pajak PBB di Kecamatan Manggala cukup patuh dalam menjalani kewajiban perpajakannya.

\section{Hasil Uji Instrumen Penelitian}

\section{a. Uji Kualitas Data}

Hasil suatu penelitian seharusnya valid dan reliabel, maka untuk mendapatkan hasil tersebut dibutuhkan instrumen yang valid dan reliabel. Uji kualitas data dilakukan pada 97 Wajib Pajak PBB di Kecamatan Manggala Kota Makassar. Responden yang digunakan untuk uji coba kualitas data penelitian ini diambil dari dalam populasi dan digunakan kembali sebagai sampel penelitian. Untuk menguji apakah kualitas data yang digunakan dalam penelitian valid dan reliabel maka dilakukan uji validitas dan uji reliabilitas.

\section{1) Uji Validitas}

Uji validitas digunakan untuk mengukur sah atau valid tidaknya suatu kuesioner. Suatu kuesioner dikatakan valid jika pertanyaan pada kuesioner mampu untuk mengungkapkan sesuatu yang akan diukur oleh kuesioner tersebut. Jadi, validitas ingin mengukur apakah pertanyaan dalam kuesioner yang sudah kita buat betul-betul dapat mengukur apa yang hendak kita ukur. Mengukur validitas dapat menggunakan Pearson Correlation dan dilakukan dengan cara melakukan korelasi bivariate antara masing - masing skor indikator pertanyaan terhadap total konstruk dengan menunjukkan hasil yang signifikanya itu dibawah 0,05. Jika masing masing indikator pertanyaan mempunyai tingkat signifikansi dibawah 0,05 berarti dikatakan valid (Ghozali, 2009:49).

Hasil analisis korelasi bivariate dapat diketahui dengan melihat output Cronbach's Alpha yang ada pada kolom Correlated Item - Total Correlation. Pengujian menggunakan tingkat signifikasi $5 \%$ dengan uji satu arah, dengan kriteria pengujian sebagai berikut :

a) Apabila nilai $\mathbf{r}_{\text {hitung }}$ (pearson correlation) $<\mathbf{r}_{\text {tabel }}$ maka butir pernyataan dikatakan tidak valid.

b) Apabila nilai $\mathbf{r}_{\text {hitung }}$ (pearson correlation) $>\mathbf{r}_{\text {tabelmaka butir }}$ pernyatan dapat dikatakan valid. 
Tabel 7. Uji Validitas Data

\begin{tabular}{ccccc}
\hline Instrumen & Pernyataan & R Hitung & R Tabel & Keterangan \\
\hline \multirow{4}{*}{$\mathbf{X}_{\mathbf{1}}$} & Peng 1 & 0,768 & 0,1680 & Valid \\
& Peng 2 & 0,818 & 0,1680 & Valid \\
& Peng 3 & 0,786 & 0,1680 & Valid \\
& Peng 4 & 0,816 & 0,1680 & Valid \\
& Peng 5 & 0,735 & 0,1680 & Valid \\
& Peng 6 & 0,797 & 0,1680 & Valid \\
$\mathbf{X}_{\mathbf{2}}$ & Kesd 1 & 0,752 & 0,1680 & Valid \\
& Kesd 2 & 0,679 & 0,1680 & Valid \\
& Kesd 3 & 0,780 & 0,1680 & Valid \\
& Kesd 4 & 0,767 & 0,1680 & Valid \\
& Kesd 5 & 0,799 & 0,1680 & Valid \\
$\mathbf{Y}$ & Kesd 6 & 0,830 & 0,1680 & Valid \\
& Kept 1 & 0,880 & 0,1680 & Valid \\
& Kept 2 & 0,822 & 0,1680 & Valid \\
& Kept 3 & 0,807 & 0,1680 & Valid \\
\hline
\end{tabular}

Sumber : Output SPSS 21.0 (2017)

Tabel 7 dibawah ini dinyatakan valid, dan dapat menunjukkan hasil uji validitas pada digunakan sebagai data penelitian.

ketiga variabel yang terdiri dari

Pengetahuan, Kesadaran, dan

Kepatuhan. Berdasarkan tabel 7

menunjukkan bahwa nilai korelasi $\mathrm{r}$

hitung (pearson correlation) untuk

masing-masing pernyataan pada tiap

variabel menunjukkan angka lebih

besar dari nilai $r$ tabel sebesar 0,1680

dengan rumus degree of freedom $(d f)$

$=\mathrm{N}-2$ (taraf signifikasi 5\% dengan

$\mathrm{N}=97$ ), sehingga $\mathrm{df}=97-2=95$,

maka $\mathbf{r}_{\text {tabel }}=0,1680$. Jika $\mathbf{r}_{\text {hitung }}>$

$\mathbf{r}_{\text {tabel}}$, maka pernyataan tersebut

dikatakan valid. sehingga dapat

disimpulkan bahwa pernyataan-

pernyataan pada tiap variabel

\section{2) Uji Reliabilitas}

Suatu kuesioner dikatakan reliable atau dapat dipercaya jika jawaban seseorang terhadap pernyataan adalah konsisten atau stabil dari waktu ke waktu.. Pengujian ini dilakukan dengan menggunakan pengukuran one shot atau pengukuran sekali saja dan hasilnya dibandingkan dengan pertanyaan lain atau mengukur korelasi antar jawaban pertanyaan dengan teknik Cronbach's Alpha. Cronbach's Alpha adalah tolak ukur atau patokan yang digunakan untuk menafsirkan korelasi 
antara skala yang dibuat dengan Cronbach's Alpha >rabel dengan semua skala variabel yang ada. rumus degree of freedom $(d f)=\mathrm{N}-2$.

Pengujian menggunakan tingkat Nilai $\mathbf{r}_{\text {tabel }}$ pada penelitian ini signifikasi 5\% dengan $\mathrm{N}=97$ yang menggunakan $\mathbf{r}_{\text {tabel }}$ yang diproduksi dilakukan pada setiap butir oleh Junaidi. pernyataan pada setiap variabel.

Suatu konstruk atau variabel dikatakan reliabel jika nilai

Tabel 8.Uji Reliabilitas Data

\begin{tabular}{ccc}
\hline Instrumen & Cronbach's Alpha & Keterangan \\
\hline Pengetahuan Wajib Pajak & 0,876 & Reliabel \\
Kesadaran Wajib Pajak & 0,859 & Reliabel \\
Kepatuhan Wajib Pajak & 0,851 & Reliabel \\
\hline
\end{tabular}

Sumber : Output SPSS 21.0 (2017)

Berdasarkan tabel 8 diatas dapat dilihat bahwa variabel Pengetahuan Wajib Pajak dapat dikatakan reliabel karena nilai alpha di atas 0,60 yaitu sebesar 0,876. Variabel independen lainnya yaitu Kesadaran Wajib Pajak juga dapat dikatakan reliabel karena nilai alpha di atas 0,60 yaitu sebesar 0,859. Sedangkan untuk variabel dependennya yaitu Kepatuhan Wajib Pajak dapat dikatakan reliabel karena nilai alpha di atas 0,60 yaitu sebesar 0,851

\section{b. Uji Asumsi Klasik}

1) Uji Normalitas

$$
\text { Ghozali (2009) uji }
$$
normalitas bertujuan apakah dalam model regresi variabel dependen (terikat) dan variabel independen (bebas) mempunyai kontribusi atau tidak. Penelitian yang menggunakan metode yang lebih handal untuk menguji data mempunyai distribusi normal atau tidak yaitu dengan melihat Normal Probability Plot. Model Regresi yang baik adalah data distribusi normal atau mendekati normal, untuk mendeteksi normalitas dapat dilakukan dengan melihat penyebaran data (titik) pada sumbu 
diagonal grafik. (Ghozali, 2009).

Untuk mendeteksi normalitas data, pada penelitian ini akan dilakukan Uji Grafik Histogram dan Uji Normal P-P Plot Regression Standardized Residual serta Uji statistik One-Sample KolmogorovSmirnov Test $(K-S)$. a) Uji Grafik Histogram dan Uji Normal P-P Plot Regression

\section{Standardized Residual}

Normal tidaknya sebuah data yang terdistribusi dapat dilakukan dengan melihat Grafik Histogram dan Normal P-P Plot Regression Standardized Residual dibawah ini

\section{Gambar 2. Grafik Histogram}

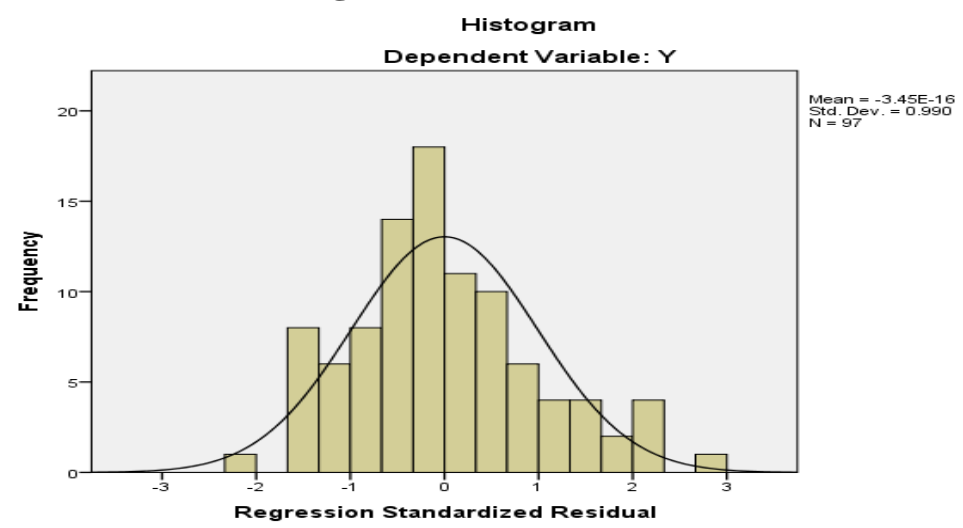

Sumber : Output SPSS 21.0 (2017)

\section{Gambar 3. Hasil Uji Normal P-P Plot Regression Standardized} Residual

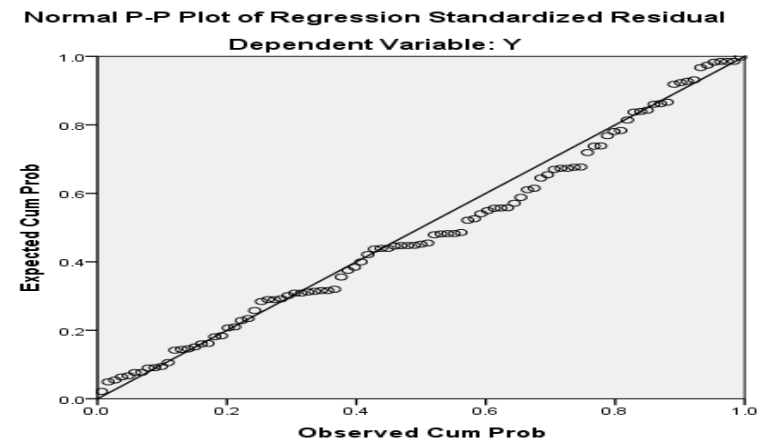

Sumber : Output SPSS 21.0 (2017)

Berdasarkan Gambar 2 dan 3, dapat dilihat Grafik Histogram maupun Grafik Normal P-P Plot
Regression Standardized Residual yang dimana Grafik Histogram memberikan pola distribusi yang 
melenceng ke kanan yang artinya adalah data berdistribusi normal. Selanjutnya, pada gambar Normal P-P Plot Regression Standardized Residual terlihat titik mengikuti dan mendekati garis diagonalnya sehingga dapat disimpulkan bahwa model regresi memenuhi asumsi normalitas.

Uji Normalitas dengan Grafik Histogram dan Normal P-P Plot Regression Standardized Residual dapat menyesatkan peneliti kalau tidak hati-hati dalam menafsirkannya. Untuk mendukung atau membuktikan hasil Uji Grafik Histogram dan normal P-P Plot Regression Standardized Residual perlu dilakukan Uji Statistik OneSample Kolmogorov-SmirnovTest $(K-S)$.

\section{b) Uji statistik One-Sample} Kolmogorov-SmirnovTest (K-S)

Tujuan dilakukan uji statistik One-Sample Kolmogorov-Smirnov Test $(K-S)$ adalah untuk menguji statistik apakah dalam model regresi, variabel residu memiliki distribusi normal atau tidak.

Dasar pengambilan keputusan uji normalitasyaitu,

1. Jika nilai Asymp. Sig. (2-tailed) $>5 \%$ atau 0,05 maka data dianggap berdistribusi normal.

2. Jika nilai Asymp. Sig. (2-tailed) $<5 \%$ atau 0,05 maka data dianggap berdistribusi tidak normal.

Hasil uji statistik One-Sample Kolmogorov-Smirnov Test (K-S) dapat dilihat pada tabel berikut: 
Tabel 9. Hasil Uji One-Sample Kolmogorov-Smirnov Test (K-S) One-Sample Kolmogorov-Smirnov Test

\begin{tabular}{llr}
\hline & & $\begin{array}{c}\text { Unstandardized } \\
\text { Residual }\end{array}$ \\
\hline $\mathrm{N}$ & & 97 \\
Normal Parameters & Mean & .0000000 \\
& Std. Deviation & 1.64505790 \\
Most Extreme & Absolute & .081 \\
Differences & Positive & .081 \\
Kolmogorov-Smirnov Z & Negative & -.041 \\
Asymp. Sig. (2-tailed) & .802 \\
a. Test distribution is Normal. & .541 \\
b. Calculated from data. & \\
Sumber : Output SPSS 21.0 (2017) &
\end{tabular}

Berdasarkan uji normalitas dengan menggunakan uji statistik One-Sample Kolmogorov-Smirnov Test diperoleh nilai KolmogorovSmirnov Z sebesar 0,802 dan Asymp. Sig. (2-tailed) sebesar $0,541>$ signifikansi $5 \%$ atau 0,05 maka dapat disimpulkan data berdistribusi normal. Hasil pengujian tersebut menunjukkan residual yang berdistribusi normal karena hasil uji histogram menunjukkan residual yang berdistribusi normal, hasil uji $P-P$ Plot juga menunjukkan nilai residual yang mendekati garis diagonal. Sementara itu nilai uji Kolmogorov-Smirnov masingmasing variabel diatas 0,05 .
Sehingga semua data variabel yang terlibat berdistribusi normal.

\section{2) Uji Multikolinearitas}

Uji Multikolinearitas bertujuan untuk menguji model regresi ditemukan adanya korelasi antar variabel bebas (independen). Model regresi yang baik seharusnya tidak terjadi korelasi atau hubungan diantara variabel bebas atau independen (tidak terjadi multikolinearitas). Jika variabel bebas saling berkorelasi, maka variabel-variabel ini tidak ortogonal (nilai korelasi antar sesama variabel bebas sama dengan nol). Dasar pengambilan keputusan uji normalitasyaitu: 
a) Melihat Nilai Tolerance:

1. Jika nilai Tolerance > 0,10 , maka Tidak Terjadi

Multikolinearitas

2. Jika nilai Tolerance $\leq 0,10$, maka Terjadi Multikolinearitas b) Melihat Nilai VIF (Variance Inflation Factor):

1. Jika nilai VIF $<10,00$, maka Tidak Terjadi Multikolinearitas

2. Jika nilai $\mathrm{VIF} \geq 10,00$, maka Terjadi Multikolinearitas

Tabel 10. Uji Multikolinearitas

\begin{tabular}{cccc}
\hline \multirow{2}{*}{ Variabel } & \multicolumn{2}{c}{ Perhitungan } & \multirow{2}{*}{ Keterangan } \\
\hline $\begin{array}{c}\text { Pengetahuan } \\
\text { Wajib Pajak } \\
\left(\mathrm{X}_{1}\right)\end{array}$ & 0,523 & 1,914 & Tidak Terjadi \\
$\begin{array}{c}\text { Kesadaran } \\
\text { Wajib Pajak } \\
\left(\mathrm{X}_{2}\right)\end{array}$ & 0,523 & & Multikolinearitas \\
& & 1,914 & $\begin{array}{c}\text { Tidak Terjadi } \\
\text { Multikolinearitas }\end{array}$ \\
\hline
\end{tabular}

Berdasarkan tabel 10 di atas, dapat disimpulkan bahwa model regresi untuk variabel independen yang diajukan oleh peneliti bebas dari multikolinearitas (tidak terjadi multikolinearitas). Hal ini dapat dibuktikan dengan melihat tabel diatas yang menunjukkan nilai Tolerance dari masing-masing variabel independen sebesar $0,523>$ 0,10 dan nilai VIF dari masingmasing variabel independen sebesar $1,914<10,00$. Dengan demikian, dapat disimpulkan bahwa seluruh variabel bebas dalam penelitian ini tidak terjadi multikolinieritas.

\section{3) Uji Heterokedastisitas}

Heterokedastisitas

menunjukkan bahwa variansi variabel tidak sama untuk semua pengamatan. Jika variansi dari residual satu pengamatan ke pengamatan yang lain tetap, maka disebut homoskedastisitas. Model regresi yang baik adalah yang homoskedastisitas atau tidak terjadi heteroskedastisitas karena data cross section memiliki data yang mewakili 
berbagai ukuran (kecil, sedang, dan besar). Untuk mendeteksi adanya Heteroskedastisitas, metode yang digunakan adalah Uji Grafik Scatterplot dan Uji Glejser.

Dasar pengambilan keputusan menggunakan Uji Grafik Scatterplot yaitu:

a) Jika ada pola tertentu terdaftar titik-titik, yang ada membentuk suatu pola tertentu yang beraturan (bergelombang, melebar, kemudian menyempit), maka Terjadi Heteroskedastisitas.

b) Jika ada pola yang jelas, serta titik-titik menyebar keatas dan dibawah 0 pada sumbu Y, maka Tidak

Terjadi

Heteroskedastisitas.

\section{Gambar 4. Uji Heterokedastisitas dengan Uji Grafik Scatterplot}

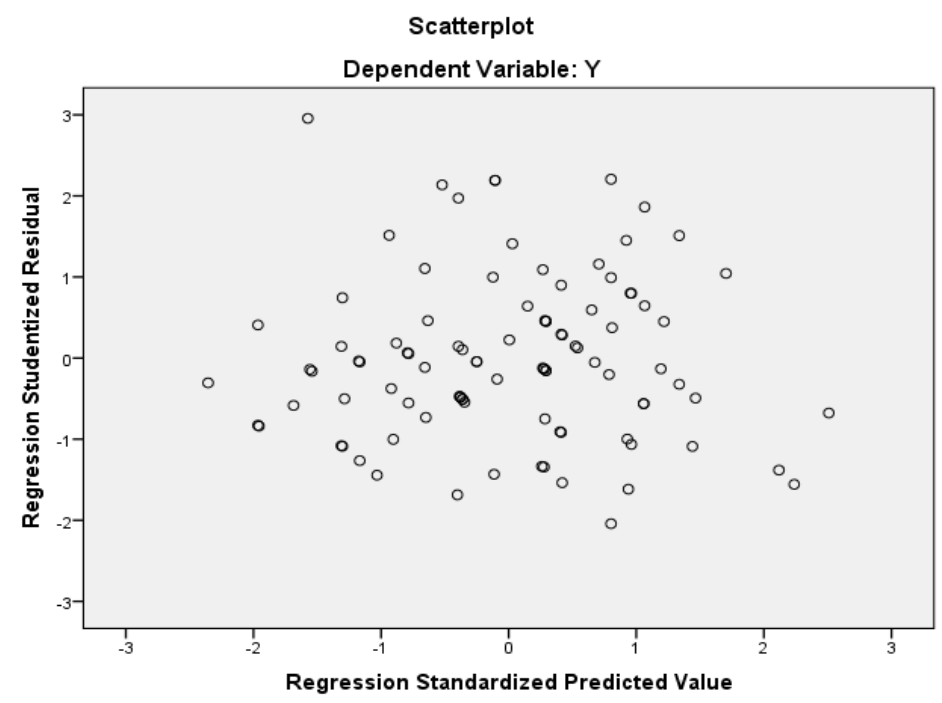

Sumber : Output SPSS 21.0 (2017)

Berdasarkan Gambar 4 grafik

Scatterplot terlihat bahwa titik-titik menyebar dan tidak membentuk pola tertentu yang jelas. Sehingga dapat disimpulkan bahwa tidak terjadi masalah heteroskedastisitas. Uji Heterokedastisitas dengan melihat Grafik Scatterplot mempunyai kelemahan yang cukup signifikan sebab jumlah pengamatan tertentu sangat mempengaruhi hasil Ploting.

Oleh sebab itu, untuk mempertegas apakah terjadi masalah heterokedastisitas atau tidak maka perlu dilakukan Uji 
Heterokedastisitas dengan $\mathrm{Uji}$

Glejser.

Dasar pengambilan keputusannya yaitu:

a) Jika nilai $t_{\text {hitung }}<t_{\text {tabel }}$ dan nilai signifikansi >0,05, maka tidak terjadi heteroskedastisitas. b) Jika jika nilai $t_{\text {hitung }}>t_{\text {tabel }}$ dan nilai signifikansi $<0,05$, maka terjadi heteroskedastisitas.

Tabel 11. Uji Heterokedastisitas menggunakan Uji Glejser

\begin{tabular}{cccc}
\hline Variabel & $\mathbf{t}_{\text {hitung }}$ & Sig. & Kesimpulan \\
\hline $\begin{array}{ccc}\text { Pengetahuan Wajib } \\
\text { Pajak }\left(\mathrm{X}_{1}\right)\end{array}$ & $-0,679$ & 0,499 & Tidak Terjadi \\
Kesadaran & & & Heterokedastisitas \\
Wajib Pajak $\left(\mathrm{X}_{2}\right)$ & 1,628 & 0,107 & Tidak Terjadi \\
Heterokedastisitas
\end{tabular}

Sumber : Output SPSS 21.0 (2017)

Berdasarkan Tabel 11 persamaan regresi sebagai berikut:

menunjukkan bahwa semua variabel bebas mempunyai nilai $\mathbf{t}_{\text {hitung }}<\mathbf{t}_{\text {tabel }} 1.66105$ dan nilai Dimana:

signifikansi > dari tingkat signifikansi $\quad \mathrm{Y} \quad$ : Kepatuhan Wajib Pajak $5 \%$ atau 0,05 . Nilai $\mathbf{t}_{\text {tabel }}$ pada $\quad X_{1} \quad$ : Pengetahuan Wajib Pajak penelitian ini menggunakan $\mathbf{t}_{\text {tabel }}$ yang $\quad \mathrm{X}_{2} \quad$ : Kesadaran Wajib Pajak diproduksi oleh Junaidi dengan rumus e : Error degree of freedom $(d f)=\mathrm{N}-2$. Oleh Persamaan regresi di atas karena itu, dapat disimpulkan bahwa mengandung makna bahwa :

tidak terjadi heteroskedastisitas dalam model regresi.

\section{c. Analisis Regresi Linear Berganda}

Dari hasil analisis dengan bantuan SPSS 21.0 maka dapat ditulis

1. Konstanta $(\alpha)$ sebesar 2,187 berarti bahwa dengan mengesampingkan pengaruh besarnya pengetahuan wajib pajak $\left(\mathrm{X}_{1}\right)$ dan kesadaran wajib pajak $\left(\mathrm{X}_{2}\right)$, maka besarnya kepatuhan wajib pajak adalah 
2,187 .

2. Koefisien regresi variabel pengetahuan wajib pajak $\left(\mathrm{X}_{1}\right)$ sebesar 0,295 berarti bahwa jika terjadi peningkatan variabel pengetahuan wajib pajak $\left(\mathrm{X}_{1}\right)$ sebesar satu satuan dengan asumsi variabel lain konstan, maka besarnya kepatuhan wajib pajak (Y) akan naik sebesar 0,295 satuan.

3. Koefisien regresi variabel kesadaran wajib pajak $\left(\mathrm{X}_{2}\right)$ sebesar 0,278 berarti bahwa jika terjadi peningkatan variabel kesadaran wajib pajak $\left(\mathrm{X}_{2}\right)$ sebesar satu satuan dengan asumsi variabel lain konstan, maka besarnya kepatuhan wajib pajak (Y) akan naik sebesar 0,278 satuan.

\section{d. Koefision Determinasi $\left(R^{2}\right)$}

Koefisien

determinasi bertujuan untuk mengukur seberapa jauh kemampuan model dapat menjelaskan variasi variabel dependen.

Tabel 12. Koefisien Determinasi $\left(\mathbf{R}^{2}\right)$

Model Summary ${ }^{b}$

\begin{tabular}{lrrrr}
\hline Model & R & R Square & $\begin{array}{c}\text { Adjusted R } \\
\text { Square }\end{array}$ & $\begin{array}{l}\text { Std. Error of } \\
\text { the Estimate }\end{array}$ \\
\hline 1 & $.798^{\mathrm{a}}$ & .637 & .629 & 1.662
\end{tabular}

a. Predictors: (Constant), X2, X1

b. Dependent Variable: Y

Berdasarkan Tabel 12 Pengetahuan $\left(\mathrm{X}_{1}\right)$ dan Kesadaran koefisien deteminasi di atas, nilai $\left(\mathrm{X}_{2}\right)$ sebesar $62,9 \%$ dan sisanya

AdjustedR Square yang diperoleh $37,1 \%$ dipengaruhi oleh variabel sebesar 0,629 yang menunjukkan lain yang belum diteliti dalam bahwa Kepatuhan Wajib Pajak PBB penelitian ini.

di Kecamatan Manggala Kota Makassar dipengaruhi oleh variabel e. Uji Hipotesis 
Untuk menguji hipotesis alat yang digunakan adalah regresi berganda. Dalam penggunaan alat uji regresi berganda terdapat beberapa analisis yang digunakan yaitu:

\section{Uji Signifikansi Parsial (Uji t)}

Uji t dimaksudkan untuk menguji apakah variabel independen (X) secara parsial berpengaruh secara signifikan terhadap variabel dependen (Y). Dengan Hipotesis:

1) $\mathrm{H}_{0} \quad=$ Variabel independen secara parsial tidak berpengaruh signifikan terhadap variabel dependen.
2) $\mathrm{H}_{1} \quad$ = Variabel independen secara parsial berpengaruh signifikan terhadap variabel dependen.

Dasar pengambilan keputusan Uji Statistik t yaitu:

a. Jika nilai probabilitas atau pvalue (nilai sig.) $>0,05$ atau $\mathrm{t}_{\text {tabel }}<\mathrm{t}_{\text {hitung }}<\mathrm{t}_{\text {tabel }}$ maka $\mathrm{H}_{0}$ diterima dan $\mathrm{H}_{1}$ ditolak.

b. Jika nilai probabilitas atau $p$ value (nilai sig.) $<0,05$ atau $t_{\text {tabel }}>t_{\text {hitung }}>t_{\text {tabel }}$ maka $\mathrm{H}_{0}$ ditolak dan $\mathrm{H}_{1}$ diterima.

Tabel 13. Uji Signifikansi Parsial (Uji t) Coefficients $^{\mathrm{a}}$

\begin{tabular}{|c|c|c|c|c|c|c|c|}
\hline \multirow[t]{2}{*}{ Model } & \multicolumn{2}{|c|}{$\begin{array}{l}\text { Unstandardized } \\
\text { Coefficients }\end{array}$} & \multirow{2}{*}{$\begin{array}{l}\text { Standardized } \\
\text { Coefficients } \\
\text { Beta }\end{array}$} & \multirow[t]{2}{*}{$\mathrm{T}$} & \multirow[t]{2}{*}{ Sig. } & \multicolumn{2}{|c|}{$\begin{array}{c}\text { Collinearity } \\
\text { Statistics }\end{array}$} \\
\hline & B & Std. Error & & & & Tolerance & VIF \\
\hline (Constant) & 2.187 & .907 & & 2.410 & .018 & & \\
\hline $1 \mathrm{X} 1$ & .295 & .057 & .443 & 5.153 & .000 & .523 & 1.914 \\
\hline $\mathrm{X} 2$ & .278 & .056 & .424 & 4.934 & .000 & .523 & 1.914 \\
\hline
\end{tabular}

a. Dependent Variable: Y

Sumber : Output SPSS 21.0 (2017

Berdasarkan tabel 13, 1) Variabel Pengetahuan Wajib Pajak diketahui tingkat signifikansi $\left(\mathrm{X}_{1}\right)$ variabel bebas terhadap variabel Variabel pengetahuan terikat. Berikut akan dijelaskan perpajakan wajib pajak PBB secara parsial pengaruh masing- memiliki nilai $t_{\text {hitung }}$ sebesar 5,153 masing variabel dalam penelitian: $\quad$ yang berarti hasil uji $t_{\text {hitung }}>t_{\text {tabel }}$ 
pada tingkat signifikan $0,05(\alpha=$ $5 \%$ ), yaitu 1,66105 dan nilai signifikan sebesar 0,000 yang berarti lebih kecil dari 0,05 $(0,000<0,05)$. Maka dapat disimpulkan bahwa pengetahuan wajib pajak $\left(\mathrm{X}_{1}\right)$ secara signifikan berpengaruh terhadap kepatuhan wajib pajak dalam membayar pajak bumi dan bangunan (PBB) di Kecamatan Manggala Kota Makassar. Hasil penelitian ini konsistensi dan sejalan dengan penelitian Utomo (2011).

2) Variabel Kesadaran Wajib Pajak $\left(\mathrm{X}_{2}\right)$

Variabel kesadaran wajib pajak memiliki nilai $t_{\text {hitung }}$ sebesar 4,934 yang berarti hasil uji $t_{\text {hitung }}$ $>\mathrm{t}_{\text {tabel }}$ pada tingkat signifikan $0,05(\alpha=5 \%)$, yaitu 1,66105 dan nilai signifikan sebesar 0,000 yang berarti lebih kecil dari 0,05 $(0,000<0,05)$. Maka dapat disimpulkan bahwa kesadaran wajib pajak $\left(\mathrm{X}_{2}\right)$ secara signifikan berpengaruh terhadap kepatuhan wajib pajak dalam membayar pajak bumi dan bangunan (PBB) di Kecamatan Manggala Kota Makassar. Hasil penelitian ini konsistensi dan sejalan dengan penelitian Khoirul Mustofa (2011).

\section{Uji Signifikansi Simultan (Uji F)}

Uji statistik $F$ pada dasarnya menunjukkan apakah semua variabel independen atau bebas yang dimasukkan dalam model mempunyai pengaruh secara bersama-sama terhadap variabel terikat/dependen. Uji F mengukur kemampuan variabel-variabel independen, yaitu Pengetahuan Wajib Pajak dan Kesadaran Wajib Pajak menjelaskan variabel dependen, yaitu Kepatuhan Wajib Pajak. Hasil pengujian untuk uji $\mathrm{F}$ (simultan) adalah sebagai berikut: 
Tabel 14. Uji Signifikansi Simultan (Uji F)

\begin{tabular}{rlrrrrr}
\multicolumn{7}{c}{ ANOVA $^{\mathbf{a}}$} \\
\hline \multicolumn{1}{c}{ Model } & Sum of Squares & \multicolumn{1}{c}{ df } & Mean Square & F & \multicolumn{1}{c}{ Sig. } \\
\hline \multirow{3}{*}{1} & Regression & 455.090 & 2 & 227.545 & 82.331 & $.000^{\mathrm{b}}$ \\
& Residual & 259.797 & 94 & 2.764 & & \\
& Total & 714.887 & 96 & & & \\
\hline
\end{tabular}

a. Dependent Variable: Y

b. Predictors: (Constant), X2, X1

Sumber : Output SPSS 21.0 (2017

Berdasarkan hasil pengolahan data pada tabel 14, menunjukkan bahwa dari uji $\mathrm{F}$ test nilai $\mathrm{F}$ hitung sebesar 82,331 dengan nilai signifikansi sebesar 0,000 atau lebih kecil dari nilai probabilitas ( $p$-value) $0,05(0,000<0,05)$, maka dapat dikatakan bahwa pengaruh pengetahuan wajib pajak dan kesadaran wajib pajak secara bersama-sama (simultan) mempunyai pengaruh yang signifikan terhadap kepatuhan wajib pajak dalam membayar pajak bumi dan bangunan di Kecamatan Manggala Kota Makassar.

\section{PEMBAHASAN}

1. Pengaruh

Pengetahuan

Terhadap Kepatuhan Wajib

Pajak Dalam Membayar Pajak

Bumi dan Bangunan (PBB) Di

\section{Kecamatan Manggala Kota}

Makassar

Hasil penelitian ini menunjukkan bahwa pengetahuan perpajakan wajib pajak berpengaruh positif signifikan terhadap kepatuhan dalam membayar pajak bumi dan bangunan di Kecamatan Manggala Kota Makassar. Artinya apabila wajib pajak dapat menerapkan pengetahuan yang mereka miliki terhadap pajak dengan benar dan tepat waktu maka pemenuhan kepatuhan perpajakan akan semakin baik pula. Dalam penelitian ini menunjukkan bahwa pengetahuan wajib pajak PBB di Kecamatan Manggala cukup rendah dalam hal mengetahui peraturan perpajakan baik itu soal manfaat, tanggal jatuh tempo, sanksi, pendaftaran sampai dengan pembayaran pajak bumi dan bangunan. Pengetahuan perpajakan 
membuat wajib pajak harus lebih aktif untuk membantu negara dalam meningkatkan kemakmuran dan kesejahteraan warga negara melalui membayar pajak.

Teori yang digunakan dalam penelitian ini sesuai dengan teori atribusi, yang dimana penerapan pengetahuan perpajakan yang berasal dari faktor eksternal dapat mempengaruhi wajib pajak dalam mengambil keputusan tentang bagaimana cara untuk melaporkan pajak.

\section{Pengaruh Kesadaran Wajib}

Pajak Terhadap Kepatuhan Wajib Pajak Dalam Membayar Pajak Bumi dan Bangunan (PBB) Di Kecamatan Manggala Kota Makassar

Hasil penelitian ini menunjukkan bahwa kesadaran wajib pajak berpengaruh positif yang signifikan terhadap kepatuhan dalam membayar pajak bumi dan bangunan di Kecamatan Manggala Kota Makassar. Artinya semakin tinggi tingkat kesadaran wajib pajak PBB di Kecamatan
Manggala maka semakin tinggi pula tingkat kepatuhan wajib pajak dalam membayar Pajak Bumi dan Bangunan. Kesadaran yang dimaksud dalam penelitian ini adalah apabila wajib pajak PBB memiliki kerelaan untuk memenuhi kewajibannya, termasuk rela memberikan kontribusi dana untuk pelaksanaan fungsi pemerintah dengan cara membayar kewajiban pajaknya (Suhardito, B \& Sudibyo, B, 1999), maka hal tersebut dapat eningkatkan kepatuhan wajib pajak PBB dalam memenuhi kewajiban perpajakannya. Dalam penelitian ini, kesadaran wajib pajak PBB di Kecamatan Manggala dapat dikatakan cukup rendah dalam hal memenuhi peraturan perpajakan seperti kesadaran wajib pajak PBB akan tujuan dan pentingnya pajak, serta tingkat kepercayaan wajib pajak terhadap aparat pajak. Maka dari itu tingkat kesadaran wajib pajak harus lebih dtingkatkan karena dengan adanya kesadaran yang tinggi dari dalam diri wajib pajak maka akan meningkatkan 
kepatuhan dalam membayar pajak bumi dan bangunan secara tepat waktu.

Sesuai dengan teori Behavioralbeliefs, berkaitan dengan kesadaranwajib pajak, yaitu

ketikasebelumindividumelakukan sesuatu,individutersebutakan memiliki keyakinan mengenai hasil yang akan diperoleh dari perilakunya,

sehinggaindividutersebutmemutus

kanbahwaakan

melakukannyaatautidak

melakukannya (Mustikasari, 2007).

\section{Pengaruh Simultan Antara} Pengetahuan Dan Kesadaran Wajib Pajak Dalam Membayar Pajak Bumi dan Bangunan (PBB) Di Kecamatan Manggala

\section{Kota Makassar}

Hasil penelitian ini menunjukkan bahwa kesadaran perpajakan, pengetahuan perpajakan berpengaruh secara simultan dalam membayar pajak bumi dan bangunan (PBB) di
Kecamatan Manggala Kota

Makassar. Variabel-variabel tersebut mempunyai pengaruh positif yang signifikan terhadap kepatuhan membayar pajak bumi bangunan (PBB) di Kecamatan Manggala Kota Makassar. Pengaruh kedua variabel ini memiliki makna bahwa semakin tinggi rendahnya pemenuhan kepatuhan dalam membayar pajak bumi dan bangunan (PBB) di Kecamatan Manggala Kota Makassar dipengaruhi oleh pengetahuan perpajakan, dan kesadaran wajib pajak.

Berkaitan dengan teori atribusi yaitu pengaruh Wajib Pajak untuk memenuhi kewajiban membayar pajak bumi dan bangunan (PBB) dapat meningkat karena dipengaruhi oleh beberapa faktor internal dan eksternal. Hasil Penelitian ini sejalan dengan penelitian yang dilakukan oleh Aditya Nugraha, dkk (2016), yang menunjukkan bahwa kesadaran perpajakan, pengetahuan perpajakan berpengaruh positif terhadap wajib pajak dalam 
memenuhi tingkat angka

kepatuhan perpajakannya.

\section{KESIMPULAN DAN SARAN}

\section{Kesimpulan}

Berdasarkan hasil penelitian yang telah dilakukan dapat diambil kesimpulan sebagai berikut:

1. Ada pengaruh positif yang signifikan antara pengetahuan wajib pajak terhadap kepatuhan wajib pajak dalam membayar pajak bumi dan bangunan.

2. Ada pengaruh positif yang signifikan antara kesadaran wajib pajak terhadap kepatuhan wajib pajak dalam membayar pajak bumi dan bangunan di Kecamatan Manggala Kota Makassar.

3. Ada pengaruh antara pengetahuan wajib pajak dan kesadaran wajib pajak terhadap kepatuhan wajib pajak secara simultan dalam membayar pajak bumi dan bangunan di Kecamatan Manggala Kota Makassar.

\section{Saran}

Saran yang dapat peneliti berikan berdasarkan hasil penelitian ini adalah:

1. Penelitian selanjutnya diharapkan dapat menambah variabel independen lainnya yang bertujuan untuk mengetahui variabelvariabel lain yang dapat mempengaruhi variabel dependen.

2. Bagi wajib pajak diharapkan untuk aktif dalam mencari informasi terkait dengan perpajakan sehingga masyarakat bisa paham mengenai hak dan kewajiban sebagai wajib pajak. Dengan demikian diharapkan dapat terciptanya masyarakat yang patuh dalam memenuhi kewajiban sebagai wajib pajak.

3. Bagi pemerintah diharapkan dapat meningkatkan sosialisasi perpajakan pada masyarakat dan meningkatkan pelayanan yang berkaitan dengan informasi maupun administrasi pajak. Sehingga wajib pajak tau kapan harus membayar dan terhindar dari sanksi perpajakan. Hal ini 
diharapkan dapat menigkatkan kesadaran masyarakat, dan akan meningkatkan kepatuhan wajib pajak sehingga akan berdampak langsung kepada penerimaan negara.

\section{DAFTAR PUSTAKA}

Ali Roshidi, Mohamad Bin Ahmad Hajah Mustofa Bin Mohd Hanefah, Mohd Asri Bin Mohd Noor. 2007. The Effects Of Knowledge On Tax Compliance Behaviors Among Malaysian Taxpayers. University

Pendidikan Sultan Idris: 1-15.

Andriani, P.J.A. 2000. Pajak dan Pembangunan. UI Press. Jakarta Devano, Sony dan Siti Kurnia Rahayu. 2006. Perpajakan: Konsep, Teori dan Isu.Jakarta: Kencana Prenada Media Group. Ernawati. 2014. Pengaruh Tingkat Pendidikan, Pendapatan, dan Kualitas Pelayanan Fiskus terhadap Kepatuhan Wajib Pajak. Skripsi. Fakultas Ekonomi dan Bisnis Universitas Hasanuddin.
Faizah, Siti. 2009. Faktor-Faktor yang Mempengaruhi Kepatuhan Wajib Pajak dalam Membayar Pajak Bumi dan Bangunan (Studi Kasus di Kecamatan Dukuhturi Kabupaten Tegal. Skripsi. Fakultas Ekonomi Universitas Negeri Semarang. Ghozali, Imam, 2009. Aplikasi Analisis Multivariate dengan Program SPSS. Semarang, Badan Penerbit UNDIP, Semarang.

Gunadi. 2005. Fungsi Pemeriksaan Terhadap Peningkatan Kepatuhan Pajak (Tax Compliance). Jurnal Perpajakan Indonesia Volume 4 Nomor 5: 4 -9 .

Hasan, M. Iqbal. 2002. Pokok-pokok Materi Metodologi Penelitian dan Aplikasinya. Jakarta:

Ghalia Indonesia. http://ojs.unud.ac.id/index.php/ Akuntans i/article/view/6232 Imaniyah, N. dan Handayani, B. D. 2008. Jurnal Akuntansi, Universitas Negeri Semarang. Pengaruh Penghasilan Dan Pengetahuan Perpajakan 
Terhadap Kepatuhan Wajib

Pajak Dalam Membayar Pajak

Bumi dan Bangunan (PBB) Di

Kelurahan Tegalrejo Kota

Pekalongan Tahun 2008.

Istanto, Feri. 2010. "Analisis

Pengaruh Pengetahuan Tentang

Pajak, Kualitas Pelayanan

Pajak, Ketegasan Sanksi

Perpajakan dan Tingkat

Pendidikan Terhadap Motivasi

Wajib Pajak Dalam Membayar

Pajak”.Skripsi UIN,Jakarta.

Jackson, B.R., V.C. Milliron. (1986)

"Tax Com-pliance Research:

Findings, Problems, and

Prospects", Journal of

Accounting Literature, Vol. 5, hal 125-165.

Jatmiko, Agus Nugroho. 2006.

Pengaruh Sikap Wajib Pajak

pada Pelaksanaan Sanksi

Denda, Pelayanan Fiskus, dan

Kesadaran Perpajakan terhadap

Kepatuhan Wajib Pajak Studi

Empiris Terhadap Wajib Pajak

Orang Pribadi di Kota

Semarang. Universitas

Diponegoro: Tesis Magister

Akuntansi.
Jogiyanto, H.M. 2004. Metodologi

Penelitian Bisnis, Salah Kaprah

dan Pengalaman-pengalaman.

Yogyakarta: BPFE.

Jogiyanto, H.M.2007.SistemInformasi

Keperilakuan.Yogjakarta: Andi.

Jotopurnomo, Cindy dan Yenny

Mangoting. 2013. Pengaruh

KesadaranWajib Pajak,

Pelayanan Kualitas Fiskus,

Sanksi Perpajakan, Lingkungan

Wajib Pajak Berada Terhadap

Kepatuhan Wajib Pajak Orang

Pribadi di Surabaya. Jurnal Tax and Accounting Vol. 1 No. 1.

Kurnia Rahayu, Siti. 2010.

Perpajakan Indonesia "Konsep

dan Aspek Formal”.

Yogyakarta: Graha Ilmu

Mardiasmo. 2011. Perpajakan. Edisi

Revisi 2011. Penerbit Andi: Yogyakarta.

Muliari dan Setiawan. 2010.

Pengaruh Persepsi Tentang

Sanksi Perpajakan Dan

Kesadaran Wajib Pajak

Terhadap Kepatuhan Pelaporan

Wajib Pajak. Skripsi.

Universitas Udhayana

Denpasar. 
Mustikasari, E. 2007. Simposium Nasional Akuntansi X Makassar. Kajian Empiris tentang Kepatuhan Wajib Pajak Badan di Perusahaan Indusrti Pengolahan di Surabaya, (Online),

(http://www.lintasberita.web.id/ Akuntansi/Kumpulan

Jurnal/,diakses 8 November 2015)

Mustofa, Khoirul. 2011. Pengaruh Penghasilan dan Kesadaran Wajib Pajak Terhadap Kepatuhan Wajib Pajak Dalam Membayar Pajak Bumi dan Bangunan (PBB) Di Kelurahan Tembalang Semarang Tahun 2009. Skripsi, Jurusan Akuntansi, Fakultas Ekonomi, Universitas Negeri Semarang. Notoatmodjo. 2007. Pendidikan dan Perilaku Kesehatan. Jakarta : Rineka Cipta.

Noviani, Elly. 2005. Faktor-faktor yang Mempengaruhi Kepatuhan Wajib Pajak dalam Membayar Pajak Bumi dan Bangunan di Kelurahan Sunggingan Kecamatan Kota Kabupaten
Kudus. Skripsi. Semarang : FIS UNNES

Nugroho, A, dkk. 2016. Pengaruh Kesadaran Wajib Pajak dan Pengetahuan Perpajakan Wajib Pajak Terhadap Kepatuhan Wajib Pajak Dalam Membayar Pajak Penghasilan (studi kasus pada KPP Semarang Candi), Journal Of Accounting, Volume 2 No. 2.

Nurmantu, Safri. 2003. Pengantar Perpajakan, edisi dua. Jakarta: Granit.

Oktaviani, Hana. 2011. Kesadaran Masyarakat dalam Membayar Pajak Bumi dan Bangunan di Kecamatan Gajah Mungkur Kota Semarang. Skripsi, Jurusan Hukum dan Kewarganegaraan, Fakultas Ilmu Sosial, Universitas Negeri Semarang.

Purwono, Herry. 2010. Dasar-dasar perpajakan dan akuntansi. Semarang: Erlangga.

Resmi, Siti. 2005. Perpajakan Teori dan Kasus. Salemba Empat. Jakarta. 
Resmi, Siti. 2008. Perpajakan Teori dan Kasus 4. Salemba Empat. Jakarta.

Sairi, Muhammad, dkk. 2014. Jurnal Akuntansi: Fakultas Ekonomi, Universitas Jember (UNEJ). Pengaruh Sikap, Kesadaran Wajib Pajak dan Pengetahuan Perpajakan Dalam Membayar Pajak Bumi dan Bangunan Sebagai Pajak Daerah Di Kabupaten Probolinggo.

Soemitro, Rochmat. 2001. Pajak Bumi dan Bangunan. Bandung: Refika Aditama.

Suhardito, Bambang dan Bambang Sudibyo.1999. Pengaruh Faktor faktor yang melekat pada diri wajib pajak terhadap keberhasilan penerimaan PBB. Simposium Nasional Akuntansi II, Malang. Suryarini, Trisni dan Tarsis Tarmuji. 2007. Pengetahuan Perpajakan. Semarang: UNNES PRESS.

Susilawati, Ketut. 2013. Pengaruh Kesadaran Wajib Pajak, Pengetahuan Pajak, Sanksi Perpajakan dan Akuntabilitas Pelayanan Publik Pada Kepatuhan Wajib Pajak
Kendaraan Bermotor. E-Jurnal Akutansi. Universitas Udayana. Bali, ISSN: 2302-8556 Vol. 4, Nomor 2 Hal. 345-357.

Tuwo, V. 2016. Pengaruh Sikap Dan Kesadaran Wajib Pajak Terhadap Kepatuhan Wajib Pajak Bumi dan Bangunan Di Kelurahan Tara-Tara Kota Tomohon. Universitas Sam Ratulangi, Jurnal EMBA Vol.4 No.1.

Ulfa, I. H dan Ratnawati, J. 2015. Jurnal Akuntansi: Fakultas Ekonomi dan Bisnis, Universitas Dian Nuswantoro. Pengaruh Kesadaran, Pengetahuan Pajak dan Sikap Wajib Pajak Terhadap Kepatuhan Wajib Pajak Pekerjaan Bebas Di KPP Pratama Semarang Timur.

Undang-Undang Republik Indonesia Nomor28 Tahun 2007 tentang Ketentuan Umum dan TataCaraPerpajakan.2013.Ban dung:Fokusindo Mandiri.

Undang-Undang Republik Indonesia Nomor 28 Tahun 2009 Tentang 
Pajak Daerah dan Retribusi

Daerah.

Utomo, B.A, Wahyu. (2011).

Pengaruh Sikap, Kesadaran

Wajib Pajak dan Pengetahuan

Perpajakan Terhadap

Kepatuhan Wajib Pajak Dalam

Membayar Pajak Bumi dan

Bangunan Di Kecamatan

Pamulang Kota Tangerang

Selatan. Skripsi, Jurusan

Akuntansi, Fakultas Ekonomi

Dan Bisnis, Universitas Islam

Negeri Syarif Hidayatullah

Jakarta

Widayati dan Nurlis. 2010. Faktor-

Faktor yang Mempengaruhi

Kemauan Untuk Membayar
Pajak Wajib Pajak Orang Pribadi yang Melakukan Pekerjaan Bebas (Studi kasus pada KPP Pratama Gambir Tiga). Simposium Nasional Akuntansi 13

Yulsiati, Henny. 2015. Analisis Pengaruh Sikap, Kesadaran Wajib Pajak, Pengetahuan Perpajakan Dan Pemahaman Peraturan Perpajakan Terhadap Kepatuhan Wajib Pajak Dalam Membayar Pajak Bumi dan Bangunan Di Kecamatan Kemuning Kota Palembang. Jurnal Akuntanika, No. 1 , Vol. 2, Politeknik Negeri Sriwijaya. 